\title{
Occurrence of Arsenic in Ground Water in the Choushui River Alluvial Fan, Taiwan
}

\author{
Chen-Wuing Liu,* Sheng-Wei Wang, Cheng-Shin Jang, and Kao-Hong Lin
}

\begin{abstract}
An investigation of shallow ground water quality revealed that high arsenic (As) concentrations were found in both aquifers and aquitards in the southern Choushui River alluvial fan of Taiwan. A total of 655 geological core samples from 13 drilling wells were collected and analyzed. High As contents were found primarily in aquitards, to a maximum of $590 \mathrm{mg} / \mathrm{kg}$. The contents were correlated with the locations of the marine sequences. Additionally, strong correlations among the As concentrations of core samples, the clay, and the geological age of the Holocene transgression were identified. Most of the As in ground water originated from the aquitard of the marine sequence. The high As content in marine formations with high clay contents may be attributable to the bioaccumulation of As in the sea organisms, which accrued and were deposited in the formation. A preliminary geogenic model of the origin of the high As concentration in the shallow sedimentary basin of the Choushui River alluvial fan of Taiwan is proposed.
\end{abstract}

$\mathrm{H}^{\mathrm{s}}$ IGH ARSENIC CONCENTRATIONS in deep well water have been verified to be associated with blackfoot disease, which was once common on the Chianan Plain in Taiwan (Tseng, 1997; Chiou, 1996; Chi and Blackwell, 1968; Shen and Chin, 1964). Total As concentrations in deep well water range from 0.47 to $0.897 \mathrm{mg} / \mathrm{L}$ in this hyperendemic blackfoot disease area (Chen et al., 1994). The strong contamination of ground water by As has also been observed in shallow tubewells in Bangladesh to depths of 15 to $30 \mathrm{~m}$ (Kinniburgh, 2001). The highest As concentration of ground water has been generally monitored in southeastern Bangladesh, close to the Bay of Bengal (Gaus et al., 2001). Extensive As contamination in ground water in Bangladesh represents a significant health risk to millions of people (Chowdhury et al., 2000; Karim, 2000). Smedley and Kinniburgh (2002) indicated that extreme As concentrations in natural water are rare, but are most frequently observed in ground water. Release from natural sources is the dominant cause of elevated As concentrations in ground water (Nordstrom, 2002; Smedley and Kinniburgh, 2002; Welch et al., 2000). From 1999 to 2003, the Taiwan Sugar Company (2003) undertook a ground water quality survey of 103 wells in the southern Choushui River alluvial fan, which is in the north of the Chianan Plain. The As concentrations of 34 well samples measured in 1999 exceeded the current

C.-W. Liu, S.-W. Wang, and C.-S. Jang, Department of Bioenvironmental Systems Engineering, National Taiwan University, Taipei, Taiwan, 106, ROC. K.-H. Lin, Research Center for Environment and Resources Management, National Chen Kung University, Tainan, Taiwan, 701, ROC. Received 19 Apr. 2005. *Corresponding author (lcw@gwater.agec.ntu.edu.tw).

Published in J. Environ. Qual. 35:68-75 (2006).

Technical Reports: Heavy Metals in the Environment doi:10.2134/jeq2005.0129

(c) ASA, CSSA, SSSA

677 S. Segoe Rd., Madison, WI 53711 USA drinking water supply standard of $0.05 \mathrm{mg} / \mathrm{L}$ in Taiwan. Similar results occurred in 2000 and 2003. The concentrations of As in ground water measured in these three years followed a log-normal distribution, as determined by a chi-square test and a Kolmogorov-Smirnov test. They have a geometric mean of $0.262 \mathrm{mg} / \mathrm{L}$ with a maximum of $0.60 \mathrm{mg} / \mathrm{L}$ and a geometric standard deviation of $1.492 \mathrm{mg} / \mathrm{L}$ (Fig. 1). These monitoring wells were distributed over the southern Choushui River alluvial fan, which is close to the blackfoot disease hyperendemic area. However, the As concentration in ground water was high in shallow monitoring wells with depths of about 20 to $70 \mathrm{~m}$ underground in Yun-Lin county (Fig. 2a), the southern part of the Choushui River alluvial fan, and differs from that in deep wells with depths of 70 to $300 \mathrm{~m}$, in the blackfoot disease hyperendemic area (Fig. 2b) (Tainan Hydraulic Laboratory, 2002; Taiwan Sugar Company, 2000).

The As contents of core samples at Ghaigang of the Chianan Plain were analyzed (Bi, 1994). The average concentration of the core samples was $9.8 \mathrm{mg} / \mathrm{kg}$. The maximum concentration of $26 \mathrm{mg} / \mathrm{kg}$ was found $105 \mathrm{~m}$ below the ground. Several works have addressed the high As content in the deep strata of the Chianan Plain, indicating that the high As contents of the core samples are related to the formations of the marine sequences (Chen, 2003; Lee, 2000; Hsia, 1997; Lin, 1995; Yen et al., 1980). Ground water is utilized abundantly as an alternative to surface water, especially in the southwestern coastal region, including in Yun-Lin county, where surface water resources are seriously deficient, because of the high domestic, irrigational, aquacultural, and industrial demand. The quantity of ground water pumped annually in Yun-Lin is 660 million $\mathrm{m}^{3}$, which is three times that in Tainan county (Agricultural Engineering Research Center, 1999; Jang, 1996). Residents may be directly exposed to As through drinking water or indirectly exposed to As through various paths, including ingesting aquacultural and agricultural products, which pose risks to human health. Accordingly, the purposes of this study are to analyze As concentration distributions in formations of the Choushui River alluvial fan; determine the correlations among As concentration distribution, material in the core sample, and geologic ages of formation; and postulate the As sources of ground water in the southern Choushui River alluvial fan of Taiwan. These results can be applied to evaluate As contamination potential and safety concerning the domestic use of ground water in the future.

\section{MATERIALS AND METHODS}

\section{Study Area}

The Choushui River alluvial fan of Taiwan includes ChangHwa county and Yun-Lin county. The latter is located in 


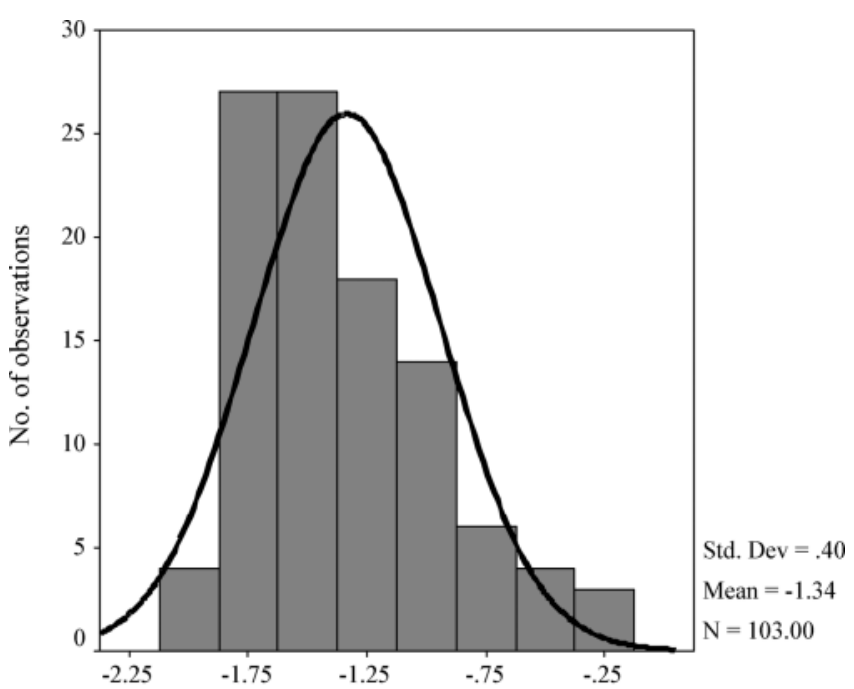

Logarithmic As concentration $\mathrm{mg} / \mathrm{L}$

Fig. 1. Log-normal distribution of 3-yr averaged As concentration in the ground water of the southern Choushui River alluvial fan in Taiwan. The dotted line represents the current drinking water standard of As concentration $(0.05 \mathrm{mg} / \mathrm{L})$ in Taiwan.

the southern part of the Choushui River alluvial fan, and is surrounded by the Taiwan Strait to the west, the Central Mountain to the east, the Choushui River to the north, and the Peikang River to the south (Fig. 3). Choushui and Peikang are the two major rivers that flow through the area, which is approximately $1000 \mathrm{~km}^{2}$, and extends $48 \mathrm{~km}$ from east to west and $24 \mathrm{~km}$ from north to south. The south side of the Choushui River alluvial fan has 107 monitoring wells, including 23 wells in Aquifer 1 with depths of under $50 \mathrm{~m}, 54$ wells in Aquifer 2 with depths of between 60 and $180 \mathrm{~m}$, and 24 wells in Aquifer 3 with depths of between 190 and $280 \mathrm{~m}$. A further six wells have depths of over 280 m (Taiwan Sugar Company, 1997).

A hydrogeological study revealed that the Choushui River alluvial fan was formed in the late Quaternary and is partitioned mainly into the proximal-, mid-, and distal-fan areas (Central Geological Survey, 1999). According to the subsurface hydrogeological analysis to a depth of around $300 \mathrm{~m}$, the formation is divided into six interlayered sequences, including three marine sequences and three nonmarine sequences, in the distal- and mid-fan areas, respectively. Generally, the nonmarine sequences of formation, with coarse sediment, ranging from medium sand to gravel of high permeability, can be regarded as aquifers, whereas the marine sequences of formation, with fine sediment, can be regarded as aquitards. The hydrogeological formation of the proximal fan, which consists entirely of gravel and sand, is considered to be an unconfined aquifer and an important ground water recharge area. Huang (1996) employed accelerator mass spectrometry C-14 dating to determine the ages of mollusk shells within the sedimentary basin of the Choushui River alluvial fan. He determined that the Marine Sequence 1 was deposited 3000 to $9000 \mathrm{yr}$ ago during the Holocene transgression, Marine Sequence 2 was dated 35000 to $50000 \mathrm{yr}$ ago, and Marine Sequence 3 was probably deposited 80000 to $120000 \mathrm{yr}$ ago during the more recent interglacial transgression. These data were collected and analyzed to determine the correlations among the As concentration distribution, material in the core samples, and geologic ages of the formations.

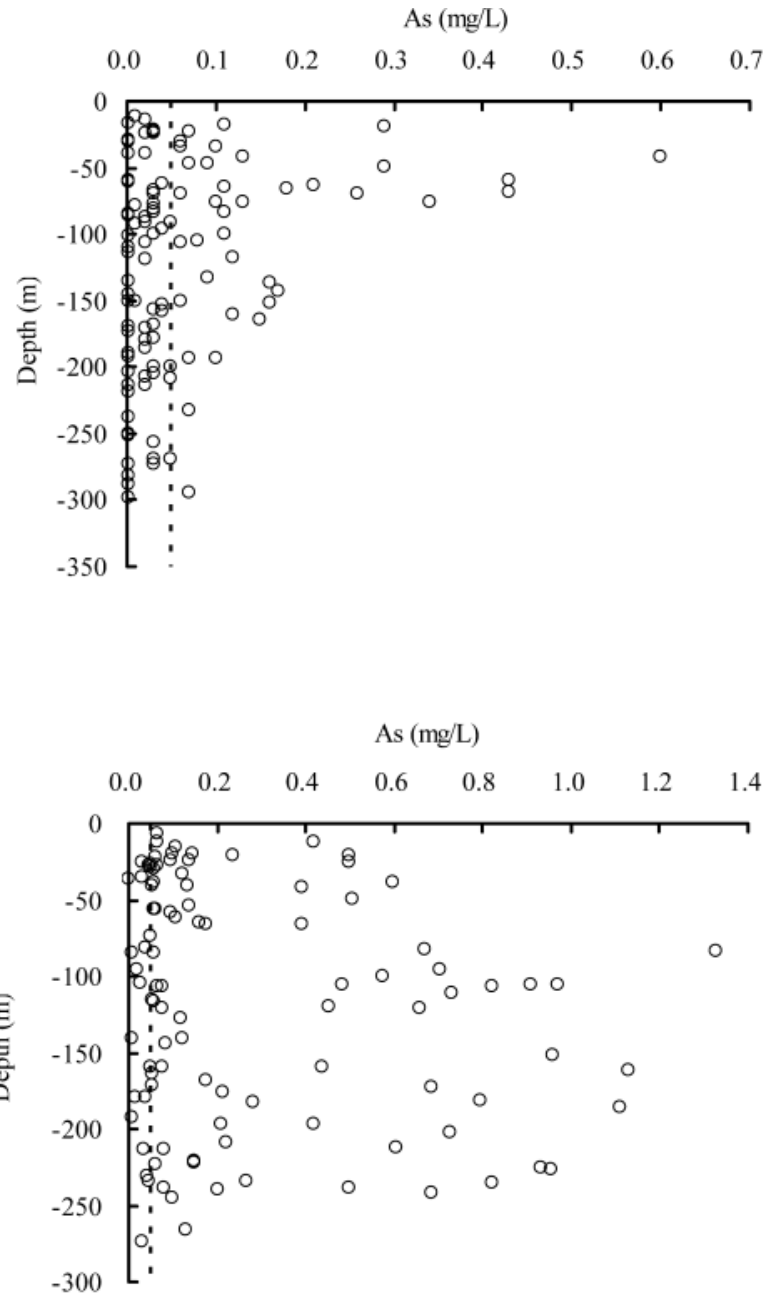

(a)

(b)

Fig. 2. The 3-yr averaged As concentration distribution in the (a) southern Choushui River alluvial fan and (b) the Chianan Plain. The dotted line represents the current drinking water standard of As $(0.05 \mathrm{mg} / \mathrm{L})$ in Taiwan.

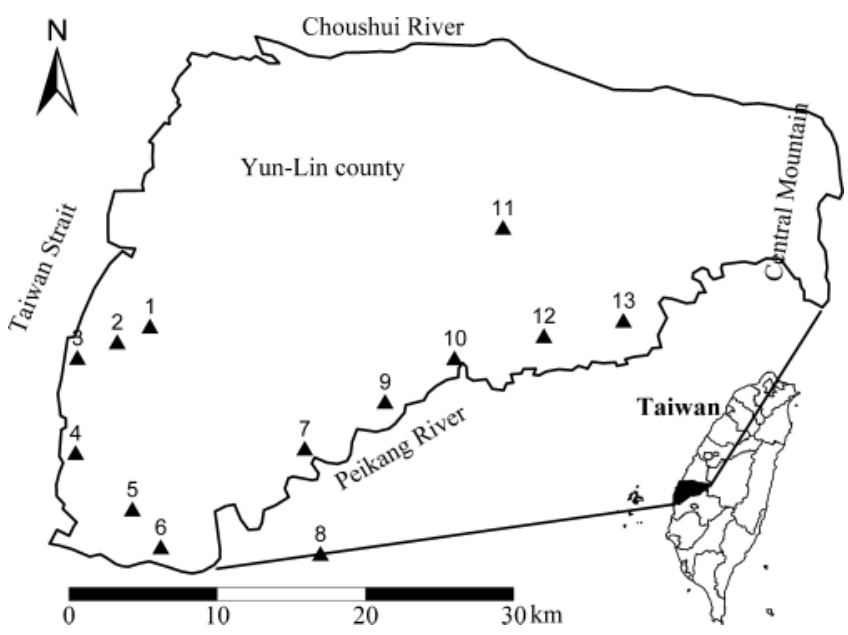

Fig. 3. Study area. Geological core samples were collected from 13 drilling stations in Yun-Lin county, at 3- or 10-m intervals to a depth of $300 \mathrm{~m}$. 


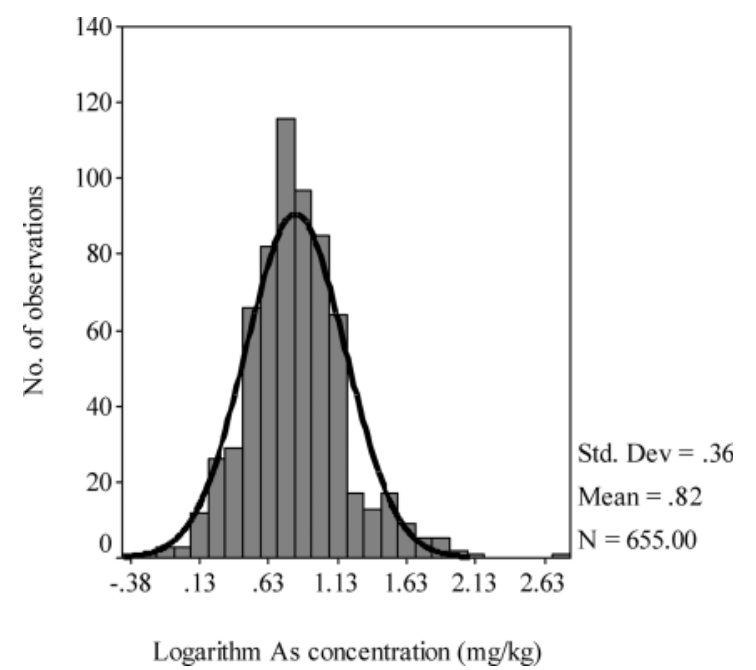

Fig. 4. Analyzed As concentrations of the 655 core samples agree with a log-normal distribution.

\section{Sampling and Analysis}

Geological core samples were collected from 13 drilling stations in southern Yun-Lin county, which are close to coastal and vicinal blackfoot disease hyperendemic areas (Fig. 3). The As concentration of ground water was high in the shallow monitoring wells of the Choushui River alluvial fan (Tainan Hydraulic Laboratory, 2002), so core samples were collected at 3-m intervals to a depth of $100 \mathrm{~m}$ below sea level, and at 10-m intervals from that depth to the bottom of the well. The As contents of a total of 655 geological core samples were analyzed.

A $30 \% \mathrm{H}_{2} \mathrm{O}_{2}$ and $9.6 \mathrm{M} \mathrm{HCl}$ solution was added to geological core samples to remove organic matter. After filtering, all samples were examined using an electro-thermal atomic absorption spectrometer (AA100; PerkinElmer, Wellesley, MA) and a hydride generation system (FIAS100; PerkinElmer); $0.5 \% \mathrm{NaBH}_{4}$ in $0.25 \% \mathrm{NaOH}$ and $1 \mathrm{M} \mathrm{HCl}$ were added to reduce arsenic to arsine. Finally, the total As concentration was determined.

\section{RESULTS AND DISCUSSION \\ Distribution of Arsenic Contents in the Sedimentary Basin}

The analyzed As concentrations of total 655 samples have a geometric mean, geometric standard deviation, minimum, and maximum of 2.27, $1.43,0.45$, and $590 \mathrm{mg} /$ $\mathrm{kg}$, respectively. Figure 4 plots the determined goodness-of-fit of the log-normal distribution of As concentrations, based on the measured As concentrations of 655 core samples. The numbers of samples with As concentrations of 0 to 10,10 to 50 , and $>50 \mathrm{mg} / \mathrm{kg}$ are 486,155 , and 14, respectively. These values exceed the average concentrations in the earth's crust $(1.8 \mathrm{mg} / \mathrm{kg})$ and in sandstone or limestone $(1 \mathrm{mg} / \mathrm{kg})$, which are the dominant sedimentary rock types in the fan (ValetteSilver et al., 1999). Pearce et al. (2001) found As concentrations of 0.4 to $10.3 \mathrm{mg} / \mathrm{kg}$ (with a median of $2.1 \mathrm{mg} /$ $\mathrm{kg}$ ) in 21 sediment samples from Chapai Nawabganj, Faridpur, and Lakshmipur in Bangladesh. Foster et al. (2000) found As concentrations of 1 to $16 \mathrm{mg} / \mathrm{kg}$ in a sediment profile from Brahmanbaria, northeastern Bangladesh. Although, in their studies, the maximum
As concentration of $264 \mathrm{mg} / \mathrm{kg}$ was found in an ironrich clay layer, the As content in this study exceeds the values found in sedimentary formations.

The horizontal and vertical cross-sections of the As concentration distributions demonstrate that the As content is high primarily in sediments of marine origin aquitards (Fig. 5), and the As concentrations decrease from the western coastal area, which has six interlayered sequences of formation, to the eastern mountainous area where the formation becomes a single gravel aquifer. Furthermore, the As concentrations in the shallow strata to a depth of $50 \mathrm{~m}$, which were formed during the Holocene transgression, are higher than those in the other strata. At Drilling Stations 5, 6, 8, and 10, As concentrations are high at depths of below $200 \mathrm{~m}$, because these drilling stations are near the Chianan Plain where deep ground water had high As concentrations. The As concentration is highest at a depth of $54 \mathrm{~m}$ at Drilling Station 1 and the As content of ground water in this region is also highest in the Choushui River alluvial fan. Drilling Stations 3 and 4, which are located near the coast, have high As contents in both shallow and deep strata. The locations of Drilling Stations 3 and 4, in the transition zone between shallow to deep, have high As content formations, which may be responsible for the high As concentrations found in both shallow and deep strata.

\section{Correlations among Arsenic Contents, Sediment Material, and Geological Ages of Core Samples}

Arsenic content $(>50 \mathrm{mg} / \mathrm{kg})$ is high mainly at Drilling Stations 1, 3, and 10 (Table 1), but the depths with high As content vary among the stations. Drilling Station 1 exhibited a high As content in the shallow stratum, Drilling Station 3 had a high As content in the deep stratum, and Drilling Station 10 had a high As content in both shallow and deep strata. The high As contents in the cores may be strongly associated with the sediment material of the core samples and the geological ages of their formation. The sediment material of the core samples in Drilling Station 1 associated with Marine Sequence 1 is clay, but the clay layer in Drilling Station 3 was during the formation of Marine Sequence 2. Additionally, clay layers were found in both Marine Sequences 1 and 2 at Drilling Station 10. Not only does the high As content of the core samples correlate closely with the presence of clay, but also the medium to low As content correlates with the presence silt and sand sediment materials. Figure 6 reveals that the logarithm of the As concentrations of the three sediment materials of the core samples-clay, silt and sand-are determined by the goodness-of-fit to a normal distribution, as determined by a chi-square test with a $5 \%$ level of significance. The logarithms of the As concentrations in clay, silt, and sand are $0.94 \pm 0.38[\mathrm{log}(\mathrm{mg} / \mathrm{kg})], 0.79 \pm$ $0.35[\log (\mathrm{mg} / \mathrm{kg})]$, and $0.69 \pm 0.29[\mathrm{log}(\mathrm{mg} / \mathrm{kg})]$, respectively. The small grains of the sediment materials have a large surface area, increasing the adsorption of As onto the surface of the solid (Smith et al., 1998). This result explains why the As concentration decreases from the distal-fan area, which consists of fine sediments, to the 


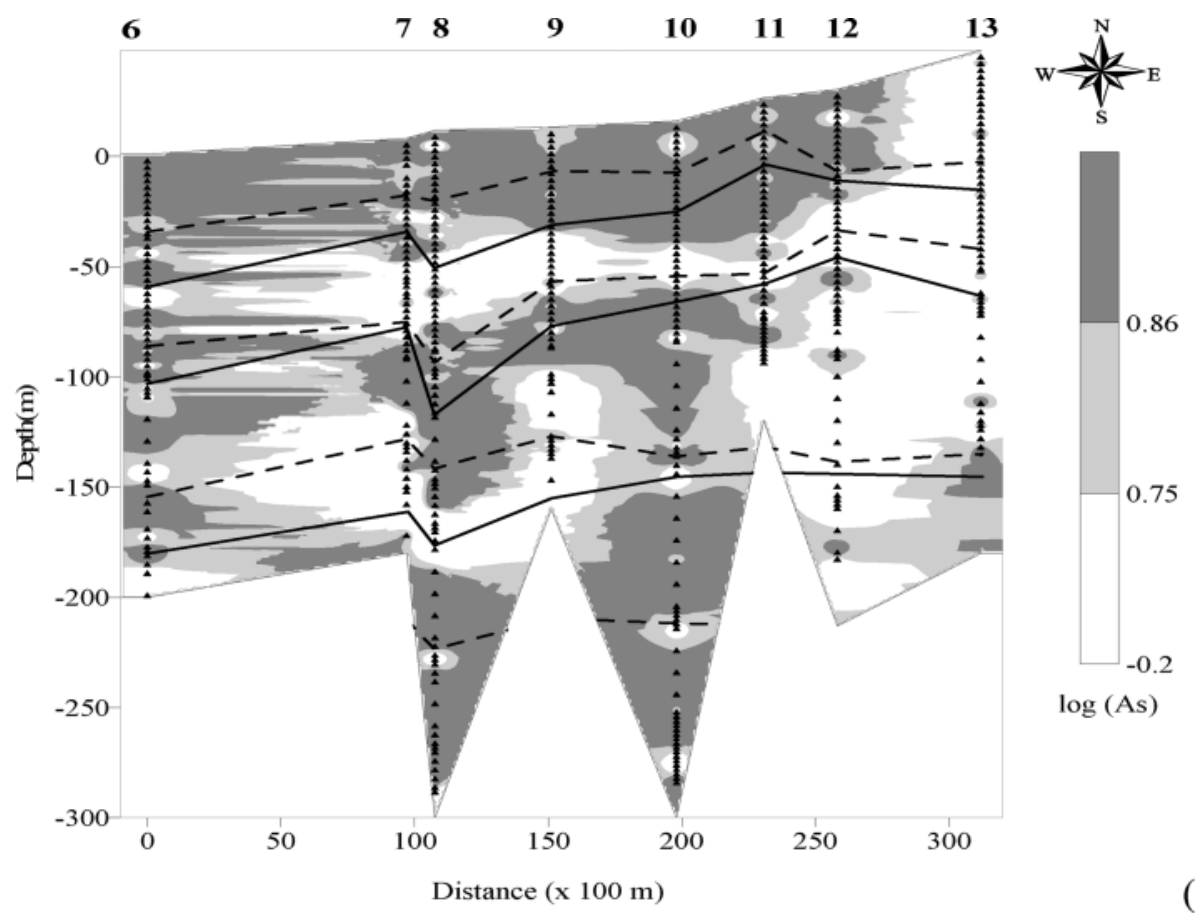

(a)

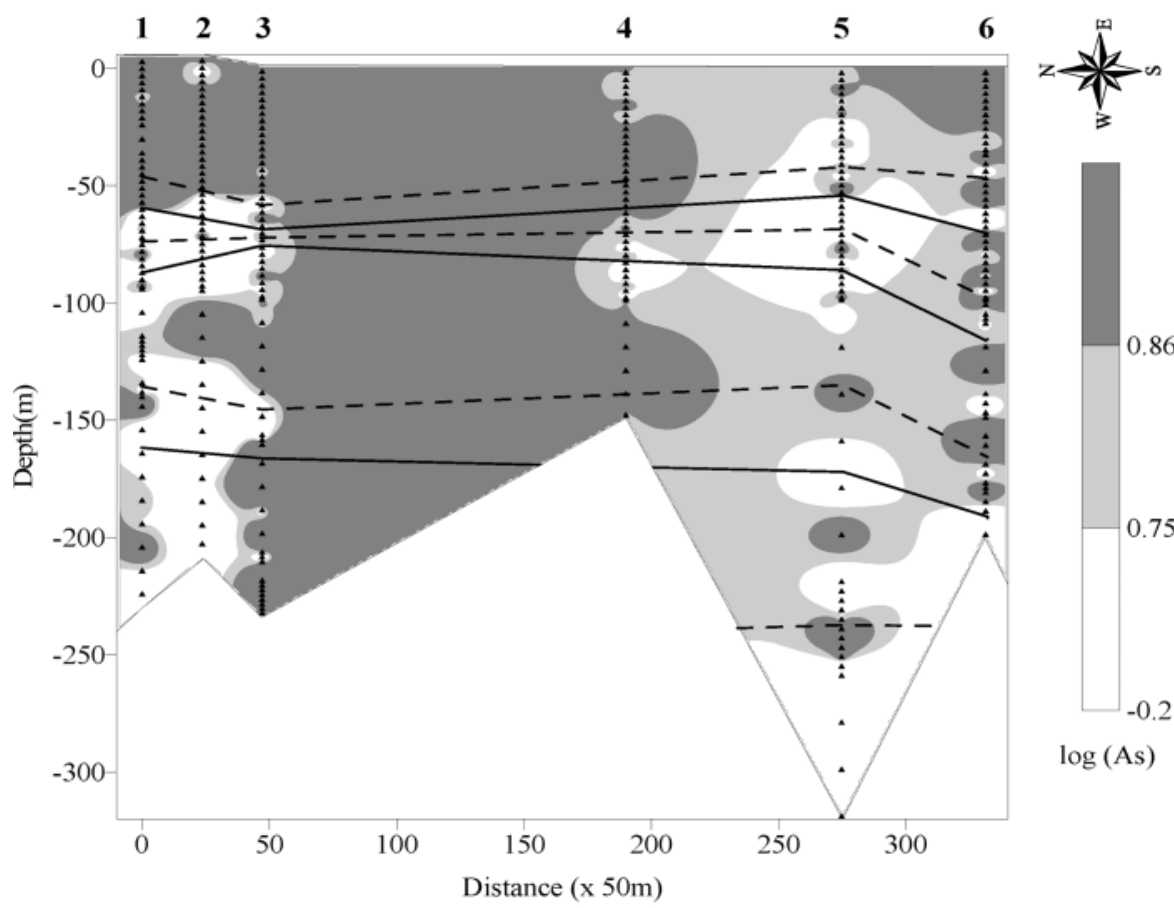

(b)

Fig. 5. Cross-sectional view of horizontal and vertical As content (mg/kg) distributions. (a) Drilling stations in the west-east direction. (b) Drilling stations in the north-south direction. The dotted and solid lines represent the tops of the aquitards and the aquifers, respectively. The solid triangles represent the locations at which the cores were sampled. The number on the top of each figure specifies the drilling station.

proximal-fan area, which consists of primarily coarse sediments.

The data from the accelerator mass spectrometry C-14 dating of mollusk shells in the core samples of the Choushui River alluvial fan (Central Geological Survey, 1999) suggest that the geologic ages of the core samples can be grouped (Table 2) as follows: 2931 to $5364 \mathrm{yr}$ ago, 7090 to $9230 \mathrm{yr}$ ago, and $>36400 \mathrm{yr}$ ago. The first two intervals are associated with the formation of Marine Sequence 1, and the third is associated with the formation of Marine Sequence 2. The As concentrations of the core samples in the second interval exceed those in the other two intervals, and the highest As concentration is $51.35 \mathrm{mg} / \mathrm{kg}$. Based on the classification of the sedimentation sequences (Huang, 1996), the second interval corresponds to the bottom of Marine Sequence 
Table 1. Drill stations and depths of core samples with As concentrations greater than $50 \mathrm{mg} / \mathrm{kg}$.

\begin{tabular}{|c|c|c|}
\hline Drill station & Depth & As concentration \\
\hline & m & $\mathrm{mg} / \mathrm{kg}$ \\
\hline 1 & 54 & 590.00 \\
\hline 3 & 162 & 117.00 \\
\hline 3 & 180 & 107.50 \\
\hline 8 & 130 & 102.60 \\
\hline 1 & 63 & 76.80 \\
\hline 1 & 6 & 75.35 \\
\hline 10 & 39 & 75.08 \\
\hline 10 & 272 & 74.64 \\
\hline 10 & 152 & 67.48 \\
\hline 11 & 30 & 61.88 \\
\hline 10 & 21 & 56.55 \\
\hline 8 & 12 & 54.90 \\
\hline 1 & 60 & 52.35 \\
\hline 3 & 51 & 51.35 \\
\hline
\end{tabular}

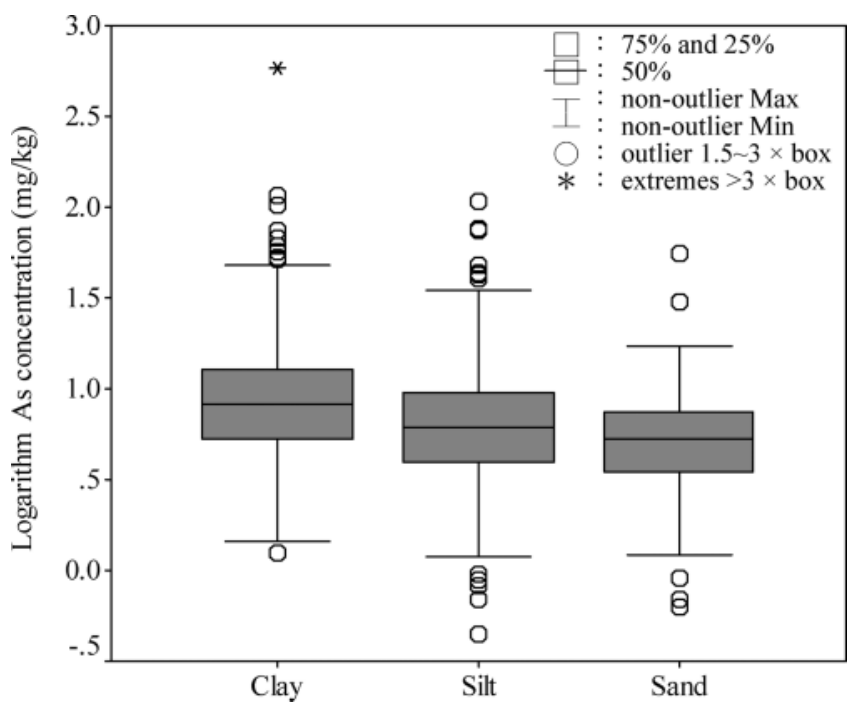

Fig. 6. Box-plot of the logarithm of As concentration in clay, silt, and sand of core samples.

Table 2. Geological dating and As contents of core samples.

\begin{tabular}{lrcr}
\hline Drill station & Depth & Dating & As concentration \\
\hline & $\mathbf{m}$ & $\mathbf{y r}$ & $\mathbf{m g} / \mathbf{k g}$ \\
$\mathbf{1}$ & $\mathbf{1 0 8 . 4}$ & $>\mathbf{5 2} \mathbf{0 0 0}$ & $\mathbf{5 . 3 2}$ \\
$\mathbf{3}$ & $\mathbf{3 2 . 7}$ & $\mathbf{2 9 3 1} \pm \mathbf{8 1}$ & $\mathbf{2 9 . 3 4}$ \\
$\mathbf{3}$ & $\mathbf{4 8 . 9}$ & $\mathbf{8 8 1 9} \pm \mathbf{9 9}$ & $\mathbf{5 1 . 3 5}$ \\
$\mathbf{3}$ & $\mathbf{1 1 7 . 9}$ & $\mathbf{4 3 9 0 0} \pm \mathbf{1 5 0 0}$ & $\mathbf{1 3 . 1 6}$ \\
$\mathbf{5}$ & $\mathbf{1 5 7 . 8}$ & $>\mathbf{4 5 0 0 0}$ & $\mathbf{5 . 4 3}$ \\
$\mathbf{6}$ & $\mathbf{3 9 . 4}$ & $\mathbf{3 9 3 6} \pm \mathbf{6 4}$ & $\mathbf{1 1 . 3 1}$ \\
$\mathbf{7}$ & $\mathbf{2 3 . 0}$ & $\mathbf{5 3 6 4} \pm \mathbf{8 9}$ & $\mathbf{4 . 8 3}$ \\
$\mathbf{7}$ & $\mathbf{4 2 . 7}$ & $\mathbf{8 4 4 0} \pm \mathbf{9 0}$ & $\mathbf{8 . 2 7}$ \\
$\mathbf{7}$ & $\mathbf{1 1 1 . 4}$ & $\mathbf{3 9} 900 \pm \mathbf{1 1 0 0}$ & $\mathbf{1 1 0}$ \\
$\mathbf{7}$ & $\mathbf{1 2 9 . 6}$ & $>\mathbf{5 0} \mathbf{0 0 0}$ & $\mathbf{1 . 7 1}$ \\
$\mathbf{8}$ & $\mathbf{9 1 . 6}$ & $>\mathbf{5 0} 000$ & $\mathbf{3 4 . 0 4}$ \\
$\mathbf{9}$ & $\mathbf{2 5 . 1}$ & $\mathbf{7 3 7 0} \pm \mathbf{1 0 0}$ & $\mathbf{1 0 . 8 9}$ \\
$\mathbf{9}$ & $\mathbf{2 5 . 1}$ & $\mathbf{7 6 2 0} \pm \mathbf{8 0}$ & $\mathbf{1 0 . 8 9}$ \\
$\mathbf{9}$ & $\mathbf{4 8 . 8}$ & $\mathbf{9 2 3 0} \pm \mathbf{6 0}$ & $\mathbf{2 . 6 1}$ \\
$\mathbf{9}$ & $\mathbf{6 8 . 6}$ & $\mathbf{3 6 4 0 0} \pm \mathbf{5 0 0}$ & $\mathbf{6 . 6 3}$ \\
$\mathbf{9}$ & $\mathbf{1 0 5 . 1}$ & $\mathbf{5 0 0 0 0}$ & $\mathbf{1 7 . 2 2}$ \\
$\mathbf{1 3}$ & $\mathbf{3 8 . 2}$ & $\mathbf{8 3 3 0} \pm \mathbf{6 0}$ & $\mathbf{1 1 . 5 1}$ \\
$\mathbf{1 3}$ & $\mathbf{3 8 . 8}$ & $\mathbf{7 9 2 0} \pm \mathbf{7 0}$ & $\mathbf{1 1 . 5 1}$ \\
$\mathbf{1 3}$ & $\mathbf{5 5 . 0}$ & $\mathbf{7 0 9 0} \pm \mathbf{6 0}$ & $\mathbf{3 . 3 7}$ \\
$\mathbf{1 3}$ & $\mathbf{6 0 . 0}$ & $\mathbf{7 8 5 0} \pm \mathbf{6 0}$ & $\mathbf{3 . 0 1}$ \\
$\mathbf{1 3}$ & $\mathbf{9 9 . 0}$ & $\mathbf{4 3 3 0 0} \pm \mathbf{1 3 0}$ & $\mathbf{4 . 6 1}$ \\
\hline
\end{tabular}

1 , which is mainly formed by clayey sediment. Additionally, the distribution of clay in Marine Sequence 1 is more extensive than that in Marine Sequence 2, causing considerable As accumulation.
Notably, the sedimentary basin of Bangladesh is mostly alluvium and deltaic deposits (Alam et al., 1990) and its geological age, especially in the Ganges, Brahmaputra, and Megna River floodplain (Kinniburgh and Smedley, 2001) ranges from 3000 to $10 \mathrm{c} 000 \mathrm{yr}$ ago, during the Holocene transgression (Umitsu, 1993). The correlations among the As contents, sediment material, and geological ages of the core samples observed in Bangladesh are similar to those found in the Choushui River alluvial fan of Taiwan.

\section{Arsenic Sources in Ground Water}

The correlations between the As concentrations in the ground water and in the core samples of the aquitard or aquifer are statistically analyzed to determine the primary source of As in ground water. The source of the As concentration in ground water is assumed to be the sediment phase of the formation. The formation is further classified as an aquifer or an aquitard based on the sediment material of the core samples and the hydrogeological setting. Accordingly, the As in the ground water may be released from the aquifer and the aquitard. Before the correlative analysis is performed, the vertical zone of influence of As concentration released from the upper and lower aquifer and the aquitard to the ground water must be defined. The zone of influence of the As concentration in ground water released from aquifers and aquitards is assumed to be half of the interval measured vertically from the center of the well screen to the upper and lower well screens. The measured As concentrations in the core samples of the aquifers and aquitards within the zone of influence were each averaged; the averages were used to evaluate the correlation between the As concentrations in ground water and those in each of the core samples from the aquifers and the aquitards. Figure 7 shows that the As concentrations of core samples in the aquitards were positively correlated with the As concentration in ground water, using $p<0.01$ as the threshold for significance $\left(R^{2}=0.51\right)$, but the As concentrations of the core samples in the aquifers were poorly correlated with those in the ground water $\left(R^{2}=0.21\right.$ and $\left.p>0.05\right)$. This result indicated that the As concentration of the core samples in the aquitards substantially influenced the As contents in vicinal ground water and may be the primary source of As in ground water (Lee, 2000).

The release of As from the formation to the ground water has been examined globally. Related studies have investigated the oxidation of As-bearing sulfides, the desorption of As from oxides and hydroxides, the reductive dissolution of As-bearing oxides and hydroxides, the release of As from geothermal waters, evaporative concentration, and the leaching of As from sulfides by carbonates (Smedley et al., 2003; Kim et al., 2000; Welch et al., 2000). Some researchers have proposed that the oxidation of sulfides, such as arsenopyrite or As-rich pyrite, is the dominant mechanism of the release of As. Others have posited that the bacteria-mediated mineralization of organic matter and the reductive dissolution of iron and manganese oxyhydroxides are responsible 


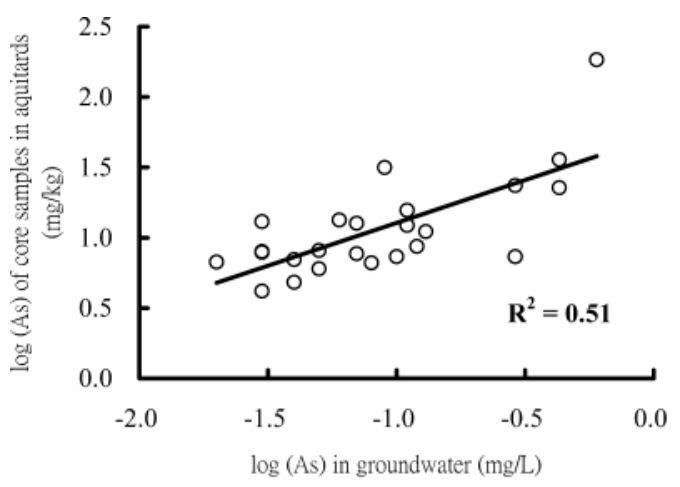

(a)

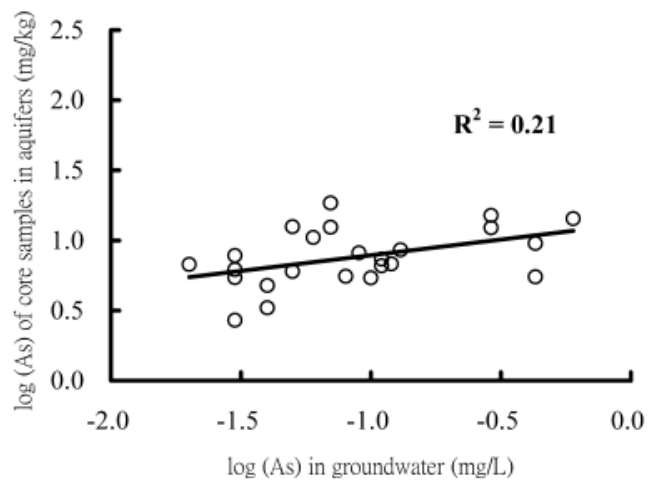

(b)

Fig. 7. (a) Correlation between As contents of core samples in aquitards and As concentration in ground water. (b) Correlation between As contents of core samples in aquifers and As concentration in ground water.

for the high concentrations of As in ground water of a sedimentary basin, such as that in Bangladesh (Anawar et al., 2003; McArthur et al., 2001; Nickson et al., 2000; Bhattacharya et al., 1997; Bagla and Kaiser, 1996; Mandal et al., 1996; Dipankar et al., 1994).

Liu et al. (2003) applied factor analysis to assess the quality of ground water in Yun-Lin county in Taiwan, and stated that the arsenic pollutant factors included As, total organic carbon, and alkalinity, which were all significantly positively correlated to each other. Anawar et al. (2003) demonstrated that the As concentrations of ground water in the Ganges delta were strongly correlated with the bicarbonate content and dissolved organic carbon (DOC), and that the combined effects of $\mathrm{NaHCO}_{3}$ and $\mathrm{pH}$ mobilized As from sediments. Harvey et al. (2002) indicated that the DOC and dissolved inorganic carbon (DIC) of ground water in Bangladesh were also positively correlated with the peak of As content to the vertical depth. The analysis of the carbon isotopes of ground water revealed the presence of young DIC and old DOC in the same water sample and demonstrated As was released from sediments to ground water. The results in our study suggest that the As in the ground water of the Choushui River alluvial fan originated from the sediment and was mostly from the marine sequence.

This study proposes a preliminary geogenic model of the origin of the high As concentration in the shallow sedimentary basin of Choushui River alluvial fan of
Taiwan. Changes in sea level significantly influence the composition and structure of the geological environment. The sedimentary basin of the Choushui River alluvial fan is formed by the alternating invasion and retreat of seawater with interlayered formations of marine and nonmarine sequences. The marine sequences comprise mainly fine sedimentary clay, ranging from clay through silt to fine sand. The high As content in the marine formation with the high clay content may be attributed to the bioaccumulation and biotransformation of As in the sea organisms, which is then accrued and deposited in the formation (Francesconi et al., 1998; Francesconi and Edmonds, 1997).

\section{CONCLUSIONS}

High As concentrations in shallow strata, and especially in aquitards, are responsible for high As concentrations in ground water in the Choushui River alluvial fan. The distribution in the sedimentary basin is caused by the alternating invasion and retreat of sea water with interlayered formations of marine and nonmarine sequences. High correlations were found among the As contents of core samples, the clay type of sediment material, and the geological ages of the Holocene transgression (Marine Sequence 1). The marine sequences were typically formed with a high clay content, increasing the As content. High As contents are thus present in the marine sequences, particularly in Marine Sequence 1. Although the depths at which the As contents were high in samples from the Choushui River alluvial fan differed from that in samples from the Chianan Plain, the geologic ages are all in the range of 3000 to $9000 \mathrm{yr}$ or the Holocene transgression. Additionally, a preliminary geogenic model is developed to describe the origin of high As concentration in the shallow sedimentary basin of the Choushui River alluvial fan in Taiwan. The source of As in ground water is postulated to originate primarily from aquitard formations of marine sequences.

Based on As geochemistry, three probable mechanisms have been offered for As mobility in ground waters of West Bengal and Bangladesh (Bose and Sharma, 2002; Mahimairaja et al., 2005). The first mechanism is mobilization of As due to the oxidation of As-bearing pyrite minerals. Insoluble As-bearing minerals such as arsenopyrite (FeAsS) are rapidly oxidized when exposed to atmosphere, releasing soluble arsenite, sulfate, and ferrous iron (Mandal et al., 1996). The dissolution of these As-containing minerals is highly dependent on the availability of oxygen and the rate of oxidation of sulfide (Loeppert, 1997). The released arsenite is partially oxidized to arsenate by microbially mediated reactions (Wilkie and Hering, 1998). The second mechanism is dissolution of As-rich iron oxy-hydroxides (FeOOH) due to the onset of reducing conditions in the subsurface. Under oxidizing conditions, and in the presence of Fe, inorganic species of As are predominantly retained in the solid phase through interaction with $\mathrm{FeOOH}$ coatings on soil particles. Onset of reducing conditions in such environments can lead to the dissolution of $\mathrm{FeOOH}$ coatings. Fermentation of peat in the subsurface releases 
organic molecules (e.g., acetate) to drive reductive dissolution of $\mathrm{FeOOH}$, resulting in the release of arsenite, arsenate, and ferrous iron present on such coatings (McArthur et al., 2001; Nickson et al., 2000). The third mechanism is release of As sorbed to aquifer minerals by competitive exchange with phosphate ions that migrate into aquifers from the application of fertilizers to surface soil (Acharyya et al., 1999). The second mechanism involving dissolution of $\mathrm{FeOOH}$ under reducing conditions is considered to be the most probable reason for excessive As accumulation in ground water of West Bengal and Bangladesh (Harvey et al., 2002; Smedley and Kinniburgh, 2002).

The process of formation of the high As content in the Choushui River alluvial fan is similar to that of As enrichment in the alluvial aquifers in West Bengal and Bangladesh, and the aforementioned release processes may be valuable in the future for determining the As release mechanism of the Choushui River alluvial fan. Future research will focus on analyzing contents of dissolved organic $\mathrm{C}$ and dissolved inorganic $\mathrm{C}$, and carbon isotopes of ground water to determine their correlations with As concentration; conducting sequential extraction experiment to identify the probable chemical forms of various ions in the sediment phase; and performing surface analysis (e.g., X-ray photoelectron spectroscopy, XPS) of sediment material to characterize the properties of As coating on the mineral surface.

\section{ACKNOWLEDGMENTS}

The authors express their gratitude to the associate editor, Professor Nanthi Bolan, and the anonymous reviewer for their constructive comments, and to the National Science Council of the Republic of China for financially supporting this research under Contract no. NSC 93-2313-B-002-071.

\section{REFERENCES}

Acharyya, S.K., P. Chakraborty, S. Lahiri, B.C. Raymahashay, S. Guha, and A. Bhowmik. 1999. Arsenic poisoning in the Gangs delta. Nature (London) 401:545.

Agricultural Engineering Research Center. 1999. Development of the estimation model for rational use of agricultural water. Res. Rep. AERC-99-RR-11. AERC, Chungli, Taiwan.

Alam, M.K., A.K.M.S. Hasan, M.R. Khan, and J.W. Whitney. 1990. Geological map of Bangladesh, scale 1:1,000,000. Geol. Survey of Bangladesh, Dhaka.

Anawar, H.M., J. Akai, K. Komaki, H. Terao, T. Yoshioka, T. Ishizuka, S. Safiullah, and K. Kato. 2003. Geochemical occurrence of arsenic in groundwater of Bangladesh: Sources and mobilization processes. J. Geochem. Explor. 77:109-131.

Bagla, P., and J. Kaiser. 1996. Epidemiology - India's spreading health crisis draws global arsenic experts. Science (Washington, DC) 274: 174-175.

Bhattacharya, P., D. Chatterjee, and G. Jacks. 1997. Occurrence of arsenic-contaminated groundwater in alluvial aquifers from delta plains, eastern India: Options for safe drinking water supply. Water Resour. Dev. 13:79-92.

Bi, R.L. 1994. A preliminary study on the arsenic enrichment of groundwater in Chianan area, Taiwan. Dep. of Geosci., Natl. Taiwan Univ., Taipei.

Bose, P., and A. Sharma. 2002. Role of iron in controlling speciation and mobilization of arsenic in subsurface environment. Water Res. 36:4916-4926.

Central Geological Survey. 1999. Project of groundwater monitoring network in Taiwan during first stage-research report of Chou-Shui River alluvial fan, Taiwan. Taiwan Water Resour. Bureau, Taipei.
Chen, C.C. 2003. Accumulation and release of arsenic in sediments from Hsindong and Jinhu in Chianan Plain, Taiwan. Dep. of Geosci., Natl. Taiwan Univ., Taipei.

Chen, S.L., S.R. Dzeng, M.H. Yang, K.H. Chiu, G.M. Shieh, and C.M. Wai. 1994. Arsenic species in groundwaters of the blackfoot disease area, Taiwan. Environ. Sci. Technol. 28:877-881.

Chi, I.C., and R.Q. Blackwell. 1968. A controlled retrospective study of blackfoot disease, an endemic peripheral gangrene disease in Taiwan. Am. J. Epidemiol. 88:7-24.

Chiou, H.Y. 1996. Epidemiologic studies on inorganic arsenic methylation capacity and inorganic arsenic induced health effects among residents in the blackfoot disease endemic area and Lanyang basin in Taiwan. Doctoral dissertation. Inst. of Epidemiology, College of Public Health, Natl. Taiwan Univ., Taipei.

Chowdhury, U.K., B.K. Biswas, T.R. Chowdhury, G. Samanta, B.K. Mandal, G.C. Basu, C.R. Chanda, D. Lodh, K.C. Saha, S.K. Mukherjee, S. Roy, S. Kabir, Q. Zaman, and D. Chakraborti. 2000. Groundwater arsenic contamination in Bangladesh and West Bengal, India. Environ. Health Perspect. 108:393-397.

Dipankar, D., C. Amit, G. Samanta, B.K. Mandal, T.R. Chowdhury, P.P. Chowdhury, C.R. Chanda, B. Gautam, L. Dilip, N. Swarup, T. Chakroborty, S. Mandal, S.M. Bhattacharya, and D. Chakraborti. 1994. Arsenic contamination in groundwater in six districts of West Bengal, India: The biggest arsenic calamity in the world. Analyst 119:168-170.

Foster, A.L., G.N. Breit, A.H. Welch, J.W. Whitney, J.C. Yount, M.S. Islam, M.M. Alam, M.K. Islam, and M.N. Islam. 2000. In-situ identification of arsenic species in soil and aquifer sediment from Ramrail, Brahmanbaria, Bangladesh. Abstract H21D-01. In Am. Geophys. Union Fall Annual Meeting, San Francisco. 15-19 Dec. 2000. AGU, Washington, DC.

Francesconi, K.A., and J.S. Edmonds. 1997. Arsenic and marine organisms. Adv. Inorg. Chem. 44:147-189.

Francesconi, K.A., W. Goessler, S. Panutrakul, and K.J. Irgolic. 1998. A novel arsenic containing riboside (arsenosugar) in three species of gastropod. Sci. Total Environ. 221:139-148.

Gaus, I., R. Webster, and D.G. Kinniburgh. 2001. Scales of variation. p. 161-173. In D.G. Kinniburgh and P.L. Smedley (ed.) Arsenic contamination of groundwater in Bangladesh. Tech. Rep. WC/00/19. British Geol. Survey, Keyworth

Harvey, C.F., C.H. Swartz, A.B.M. Badruzzaman, N. Keon-Blute, W. Yu, M.A. Ali, J. Jay, R. Beckie, V. Niedan, D. Brabander, P.M. Oates, K.N. Ashfaque, S. Islam, H.F. Hemond, and M.F. Ahmed. 2002. Arsenic mobility and groundwater extraction in Bangladesh. Science (Washington, DC) 22:1602-1606.

Hsia, M.H. 1997. Geochemistry of sediment cores from Yih-Jwu, southwestern Taiwan. Dep. of Geosci., Natl. Taiwan Univ., Taipei.

Huang, C.Y. 1996. Foraminiferal analysis and stratigraphic correlation on the subsurface geology of the Choushuichi alluvial fan. p. 55-66. In Conf. on Groundwater and Hydrogeology of Choushui River Alluvial Fan, Taipei, Taiwan. 8-9 Feb. 1996. Water Resources Bureau, Taipei.

Jang, C.S. 1996. Three dimensional numerical simulation the groundwater flow in Yun-Lin. Dep. of Agric. Eng., Natl. Taiwan Univ., Taipei.

Karim, M.M. 2000. Arsenic in groundwater and health problems in Bangladesh. Water Res. 34:304-310.

Kim, M.J., J.O. Nriagu, and S.K. Haack. 2000. Carbonate ions and arsenic dissolution by groundwater. Environ. Sci. Technol. 34:30943100.

Kinniburgh, D.G. 2001. Sorption and transport. p. 211-228. In D.G. Kinniburgh and P.L. Smedley (ed.) Arsenic contamination of groundwater in Bangladesh. Tech. Rep. WC/00/19. British Geol. Survey, Keyworth.

Kinniburgh, D.G., and P.L. Smedley (ed.) 2001. Arsenic contamination of groundwater in Bangladesh. Tech. Rep. WC/00/19. British Geol. Survey, Keyworth.

Lee, C.W. 2000. Geochemical characteristics of porewater and sediments from Kang-wei and Sin-wen, southwestern Taiwan. Dep. of Geosci., Natl. Taiwan Univ., Taipei.

Lin, Y.D. 1995. Sedimentary analysis and organic geochemistry of the Tzai-Kong and the San-Liau-Wan core and their environmental implications. Dep. of Earth Sci., Natl. Cheng-Kung Univ., Tainan, Taiwan. 
Liu, C.W., K.H. Lin, and Y.M. Kuo. 2003. Application of factor analysis in the assessment of groundwater quality in a blackfoot disease area in Taiwan. Sci. Total Environ. 313:77-89.

Loeppert, R.H. 1997. Arsenate, arsenite retention and release in oxide and sulfide dominated systems. Tech. Rep. 176. Texas Water Resour. Inst., College Station.

Mahimairaja, S., N.S. Bolan, D.C. Adriano, and B. Robinson. 2005. Arsenic contamination and its risk management in complex environmental settings. Adv. Agron. 86:1-82.

Mandal, B.K., T.R. Chowdhury, G. Samanta, G.K. Basu, P.P. Chowdhury, C.R. Chanda, D. Lodh, N.K. Karan, R.K. Dhar, D.K. Tamili, D. Das, K.C. Saha, and D. Chakraborti. 1996. Arsenic in groundwater in seven districts of West Bengal, India the biggest arsenic calamity in the world. Curr. Sci. 70:976-986.

McArthur, J.M., P. Ravenscroft, S. Safiullah, and M.F. Thirlwall. 2001. Arsenic in groundwater: Testing pollution mechanisms for sedimentary aquifers in Bangladesh. Water Resour. Res. 37:109-117.

Nickson, R.T., J.M. McArthur, P. Ravenscroft, W.G. Burgess, and K.M. Ahmed. 2000. Mechanism of arsenic release to groundwater, Bangladesh and West Bengal. Appl. Geochem. 15:403-413.

Nordstrom, D.K. 2002. Public health - Worldwide occurrences of arsenic in groundwater. Science (Washington, DC) 296:2143-2145.

Pearce, J., D.G. Kinniburgh, P.L. Smedley, K.M. Ahmed, and M. Rahman. 2001. Mineralogy and sediment chemistry. p. 187-210. In D.G. Kinniburgh and P.L. Smedley (ed.) Arsenic contamination of groundwater in Bangladesh. Tech. Rep. WC/00/19. British Geol. Survey, Keyworth.

Shen, Y.S., and C.S. Chin. 1964. Relation between blackfoot disease and the pollution of drinking water by arsenic in Taiwan. p. 173-190. In Advances in water pollution research. Pergamon Press, New York.

Smedley, P.L., and D.G. Kinniburgh. 2002. A review of the source, behavior and distribution of arsenic in natural waters. Appl. Geochem. 17:517-568.
Smedley, P.L., M. Zhang, G. Zhang, and Z. Luo. 2003. Mobilisation of arsenic and other trace elements in fluviolacustrine aquifers of the Huhhot Basin, Inner Mongolia. Appl. Geochem. 18:1453-1477.

Smith, E., R. Naidu, and A.M. Alston. 1998. Arsenic in the soil environment. A review. Adv. Agron. 64:149-195.

Tainan Hydraulic Laboratory. 2002. The Yun-Lin offshore infrastructure industrial complex. Planning, Development and Monitoring Res. Rep. Part I(7). Natl. Cheng-Kung Univ., Tainan, Taiwan.

Taiwan Sugar Company. 1997. Establishment and operational management of Groundwater Monitoring Network. Taiwan Water Resour. Bureau, Taipei.

Taiwan Sugar Company. 2000. Groundwater quality by the Taiwan Groundwater Monitoring Network (2/5). Taiwan Water Resour. Bureau, Taipei.

Taiwan Sugar Company. 2003. Groundwater quality by the Taiwan Groundwater Monitoring Network (5/5). Taiwan Water Resour. Bureau, Taipei.

Tseng, W.P. 1997. Effects and dose-response relationships of skin cancer and blackfoot disease with arsenic. Environ. Health Perspect. 19:109-119.

Umitsu, M. 1993. Late Qaternary sedimentary environments and landforms in the Ganges Delta. Sediment. Geol. 83:177-186.

Valette-Silver, N.J., G.F. Riedel, E.A. Crecelius, H. Windom, R.G. Smith, and S.S. Dolvin. 1999. Elevated arsenic concentrations in bivalves from the southeast coasts of the USA. Mar. Environ. Res. 48:311-333.

Welch, A.H., D.B. Westlohn, D.R. Helsel, and R.B. Wanty. 2000. Arsenic occurrence in groundwater of the United State: Occurrence and geochemistry. Ground Water 38:589-604.

Wilkie, J.A., and J.G. Hering. 1998. Rapid oxidation of geothermal arsenic (III) in streamwaters of the eastern Sierra Nevada. Environ. Sci. Technol. 32:657-662.

Yen, F.S., C.N. Long, and T.H. Lu. 1980. An environmental model of high arsenic concentration in the groundwater aquifer of Taiwan. J. Taiwan Environ. Sanitation 12:66-80. 